\title{
Determining the Age of Streetside Trees with Diameter at Breast Height-based Multifactorial Model
}

\author{
Jan Lukaszkiewicz and Marek Kosmala
}

\begin{abstract}
This article evaluates the possibility of determining tree age based simultaneously on diameter at breast height (dbh) (1.3 $\mathrm{m}[4.3 \mathrm{ft}])$ and total tree height using common lime, common ash, and horsechestnut species. The first step was the identification and measuring groups of trees growing in similar conditions (streetside trees in Warsaw area, Poland) in which planting ages were known (mainly from archives). Next, multifactorial regression model was developed describing the growth of both tree parameters (dbh and height) over time. In the majority of cases, plotting tree age against diameter and height yielded a regression coefficient $r$ value and determination coefficient $r^{2}$ value above 0.9 . For graphic interpretation of elaborated multifactorial models, nomograms were applied. This kind of graph allows explaining tree age based on both dbh and height of trees. Another step was verification. The resulting model was applied to unrelated groups of trees of known age. Mean bias values were established for each model. The difference between the actual age and mean age calculated with the model was less than $\pm 15 \%$. Presented model, although not meant for application to individual trees, might be useful to determine the age of groups of trees growing along streets and roads.
\end{abstract}

Key Words. Common ash; common lime; dbh-height regression model; horse chestnut; streetside trees; tree age nomograms.

The knowledge of tree age is necessary for examining growth stage and age structure in urban tree stands to ensure their proper maintenance and preservation. The tree age data find a significant potential of application in tree maintenance, especially in preparation of management plans for urban stands. These kinds of plans provide directions about frequency and benefits of maintenance aspects such as fertilizer requirements, different ways of pruning, removing trees causing threats, and planning new planting. Tree age data should be also taken into account among factors like plant species, damage rate, and location for assessment threats caused by old trees old with weakened static.

In addition to that, data concerning the relationship of tree age and dendrometric parameters is very important for determining monetary value of trees and costs of tree replacement (McPherson 2007). Tree growth formulae make possible forecasting the effect of urban trees on energy savings, atmosphere $\mathrm{CO}_{2}$ reductions, air quality benefits, storm water runoff, and the cost of tree maintenance. Research on the correlation of tree age and the growth of dendrometric parameters serves as a starting point for developing various computer programs (e.g., DISMUT [Australian National University, Canberra, Australia], eco-Smart [USDA Forest Service, Davis, CA], or Stratum [i-Tree, Kent, $\mathrm{OH}]$ ) enabling one to calculate the economic effect of trees on savings and expenditure of individual households, towns, and cities (Banks et al. 1999; Gardner 2006; McPherson 2006) or to develop tridimensional visualizations of tree growth in a changing urban environment (Linsen et al. 2005; Sterck et al. 2005). Results of tree growth research prove that savings resulting from the presence of trees in towns can be more than three times the cost of tree maintenance (McPherson et al. 2002; Geiger and McPherson 2004; Gardner 2006; McPherson 2006).

Another important benefit is the ability to provide optimum space for trees in urban plans to avoid the collision of trees with technical infrastructure and buildings (Neely 1988; Banks et al. 1999; Peper et al. 2001a; Larsen and Kristoffersen 2002, Linsen et al. 2005). It is also worth mentioning that tree age data are an important element of inventory databases for trees and urban tree stands (e.g., as planting date) developed in large cities of Western Europe, the United States, and Australia (Banks et al. 1999; Peper et al. 2001a, 2001b; Larsen and Kristoffersen 2002; Frank et al. 2006). According to Olig and Miller (1997), the United States at the end of 1990s had available on the market at least a dozen specialized programs for urban tree inventory and management such as Inventree, TreeKeeper (Davey Tree Expert Co., Kent, OH), TreeMaster (Urban Forestry Consultants, Sobrante, $\mathrm{CA}$ ), and Urban Forest Inventory (Forest Data Corp., Inverness, CA).

Until recently, the growth rates of urban trees were not well documented (McPherson 2007). The literature provides few examples of research in which tree age is a characteristic determined by noninvasive methods in situ based on dendrometric parameters. Most of the researchers (e.g., Banks et al. 1999; Peper et al. 2001a, 2001b; Larsen and Kristoffersen 2002; Grabosky and Gilman 2004; Linsen et al. 2005) focus on examining the growth of dendrometric parameters over time such as the increase of diameter at breast height (dbh), total tree height, crown radius, and leaf area. This equally concerns the research on forestry and in arboriculture. Mathematical models of exponential tree growth over time are chiefly based on the regression principle (see Pigott 1989; Brack and Wood 1998; Brzeziecki 1999; Greenberg and Simons 1999; Bolibok and Brzeziecki 2000; Peper et al. 2001b; Gutsell and Johnson 2002; Larsen and Kristoffersen 2002). The regression allows users to calculate the best fit of model parameters to data (Neter and Wassermann 1974; Sokal and Rohlf 1981; Lomnicki 2002; Motulsky and Christopoulos 2003). It is necessary to say that there is hardly any research available to present the same issue from the reverse perspective, estimating age based on dendrometric parameters. Such an approach was adopted, for instance, by Loevenstein et al. (2000), however, with reference to forest environment. 
Still lacking is an accurate in situ method based on the relationship between age and tree size. Such a method should provide an acceptable margin of error and enable rapid results. Were one available, the work of arborists would be facilitated. The present research is focused toward forecasting the age of selected streetside tree species based on dendrometric parameters: dbh and tree total height. This article presents a nondestructive method for estimating tree age based on nonlinear model of multifactorial regression and its graphic interpretationnomograms.

\section{OBJECTS AND METHODS OF RESEARCH}

The research aimed to find a method for determining the relation between tree age and two dendrometric parameters: dbh and height. These were subdivided into three basic stages:

Stage 1: field measurement of street tree populations (three selected species) in the range of known ages from young to mature, living on grass planting stripes along streets and roads, in comparable site conditions;

Stage 2: statistical analysis of collected data and determining the interdependencies as described with the mathematical equation of tree growth over time; and

Stage 3: verification (model validation) on separate tree group with known age to verify to what extent age forecasts comply with reality.

\section{Identification of Research Sites and Field Measurements}

The first stage of research done between years 2002 and 2005 consisted of determining areas for research, defined as singlespecies streetside tree plantings of uniform age. The selection of research sites accounted for plant frost resistance zones in the country. Heinze and Schreiber (1984), based on USDA Frost Hardiness Zone Map (1960), divided Poland's territory into three climactic zones with subzones. Subzone $6 \mathrm{~b}$ covers approximately $60 \%$ of the territory of Poland and is characterized by an average minimum long-term air temperature from $-20.5^{\circ} \mathrm{C}$ $\left(-4.9^{\circ} \mathrm{F}\right)$ to $-17.8^{\circ} \mathrm{C}\left(-0.04^{\circ} \mathrm{F}\right)$. All the examined trees were located in climactic subzone $6 \mathrm{~b}$, which eliminated differences in tree growth caused by varying climactic conditions in different regions of Poland. Research sites were selected also by their similar microclimactic and soil conditions (subsoil density and chemical properties of soil were taken into account). For this reason, the researchers did not include trees growing in Warsaw downtown, where tree living conditions are extremely unfavorable.

The researchers examined archive data collected during inventory of street and alley trees in Warsaw and its vicinity. To precisely determine the planting dates of some streetside tree populations, historic aerial photographs of Warsaw from 1936 and 1945 were analyzed. In some instances, researchers interviewed residents remembering when the trees were planted. The total age of street trees was established by adding 5 years to the timespan between their planting date and the present moment (e.g., Larsen and Kristoffersen 2002). This came from the practice in Poland of planting street side trees of an average age of 5 years (not younger). In some cases with the tree age still uncertain, it was additionally confirmed by the number of tree rings counted on samples taken with a Pressler borer. From each tree belonging to the investigated population, two perpendicular

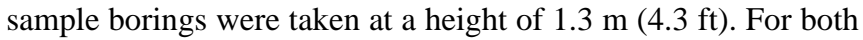
samples, age was calculated separately based on the annual ring numbers and then an average value was determined. The number of years established with the calculated annual rings was increased by 5 . This increment suggested by Assman (1968) or Kaennel and Schweingruber (2004) was necessary for the average time that is needed for tree seedling to grow up to $1.3 \mathrm{~m}$ $(4.3 \mathrm{ft})$.

The research involved three tree species most frequently planted along streets: common lime (Tilia cordata Mill.), common ash (Fraxinus excelsior L.), and horsechestnut (Aesculus hippocastanum L.). Field measurements performed between years 2004 and 2006 included dbh and circumference at $1.3 \mathrm{~m}$ $(4.3 \mathrm{ft})$ height and spacing between trees of representative age groups made respectively with a calliper, altimeter, and measuring tape. Trees had no visible symptoms of internal wood decay (e.g., cavities) and with no more than $20 \%$ crown dieback. The final inventory included 388 trees from three selected species that were used to construct the database. Initial characteristics of tree age classes involved in the research are presented in Table 1.

Many researchers (e.g., Shigo 1996; Cermak et al. 2000; Kosmala 2001; Szczepanowska 2001; Grabowsky et al. 2002) indicate that the main rooting zone of the majority of tree species is

\section{Table 1. Common lime, common ash, and horsechestnut age classes incorporated in the regression model with $\mathrm{dbh}$ and height parameters included.}

\begin{tabular}{|c|c|c|c|c|c|c|}
\hline \multirow{2}{*}{$\begin{array}{l}\text { Age } \\
\text { class } \\
\text { number }\end{array}$} & \multirow{2}{*}{$\begin{array}{l}\text { Actual } \\
\text { age } \\
\text { (years) }\end{array}$} & \multirow[b]{2}{*}{$\begin{array}{l}\text { Sample } \\
\text { size }^{\mathrm{y}}\end{array}$} & \multicolumn{2}{|c|}{ Mean dbh } & \multicolumn{2}{|c|}{$\begin{array}{l}\text { Mean tree } \\
\text { total height }\end{array}$} \\
\hline & & & $\mathrm{cm}$ (in) & $\begin{array}{l}\text { SD } \\
\pm(\mathrm{cm})\end{array}$ & m (ft) & $\begin{array}{l}\text { SD } \\
\pm(m)\end{array}$ \\
\hline 1 & 7 & 10 & $3.0(1.2)$ & 0.9 & $3.3(10.9)$ & 0.00 \\
\hline 2 & 18 & 8 & $17.0(6.8)$ & 2.7 & $5.7(18.9)$ & 0.85 \\
\hline 3 & 25 & 17 & $21.0(8.4)$ & 2.5 & $8.0(26.2)$ & 1.14 \\
\hline 4 & 34 & 22 & 29.0 (11.6) & 4.1 & $9.7(31.9)$ & 1.09 \\
\hline 5 & 34 & 18 & $24.0(9.6)$ & 4.5 & $10.1(33.3)$ & 0.73 \\
\hline 6 & 36 & 10 & $31.0(12.4)$ & 3.4 & $14.1(46.5)$ & 0.94 \\
\hline 7 & 53 & 21 & $38.0(15.2)$ & 5.9 & $12.5(41.2)$ & 1.52 \\
\hline 8 & 58 & 23 & $48.0(19.2)$ & 6.4 & $14.5(47.7)$ & 1.11 \\
\hline 9 & 75 & 18 & $54.0(21.6)$ & 4.4 & $13.8(45.5)$ & 1.60 \\
\hline \multirow[t]{2}{*}{10} & 85 & 17 & $72.0(28.8)$ & 10.2 & 20.7 (68.2) & 1.08 \\
\hline & Total & 164 & & & & \\
\hline 1 & 10 & 14 & $4.0(1.6)$ & 1.0 & $3.9(12.9)$ & 0.70 \\
\hline 2 & 15 & 9 & $12.0(4.8)$ & 2.0 & $7.1(23.3)$ & 0.70 \\
\hline 3 & 20 & 12 & $16.0(6.4)$ & 3.0 & $7.6(25.1)$ & 0.98 \\
\hline 4 & 26 & 18 & $24.0(9.6)$ & 4.0 & $9.5(31.4)$ & 1.58 \\
\hline 5 & 43 & 15 & $39.0(15.6)$ & 6.0 & $12.3(40.4)$ & 1.73 \\
\hline 6 & 45 & 17 & $44.0(17.6)$ & 5.0 & $11.6(38.2)$ & 0.82 \\
\hline \multirow[t]{2}{*}{7} & 80 & 20 & $66.0(26.4)$ & 9.0 & $23.2(76.6)$ & 1.77 \\
\hline & Total & 105 & & & & \\
\hline 1 & 16 & 11 & $13.0(5.2)$ & 2.0 & $3.7(12.1)$ & 0.52 \\
\hline 2 & 22 & 18 & $21.0(8.4)$ & 4.0 & $6.0(19.7)$ & 0.66 \\
\hline 3 & 25 & 23 & $23.0(9.2)$ & 4.0 & $5.3(17.4)$ & 0.85 \\
\hline 4 & 30 & 17 & $29.0(11.6)$ & 4.0 & $8.8(29.1)$ & 0.73 \\
\hline 5 & 38 & 14 & $32.0(12.8)$ & 6.0 & $8.1(26.8)$ & 0.78 \\
\hline 6 & 58 & 16 & $46.0(18.4)$ & 7.0 & $13.1(43.2)$ & 1.69 \\
\hline \multirow[t]{2}{*}{7} & 64 & 20 & 49.0 (19.6) & 8.0 & $13.3(44.0)$ & 1.43 \\
\hline & Total & 119 & & & & \\
\hline
\end{tabular}

${ }^{z}$ The actual age of trees taken from historical records or/and tree rings number (Pressler borer).

${ }^{\mathrm{y}}$ The total number of trees in age-homogenus population - class, taken into inventory.

$\mathrm{dbh}=$ diameter at breast height. 
contained in 0 to $30 \mathrm{~cm}$ (12 in) of the soil's surface layer. Results provided by laboratory analyses of soil structure in this layer indicate in all locations a domination of sandy clay with little humus addition (above 2\%) and $\mathrm{pH}$ value over 7.2. In each location, measurements of soil compaction with a penetrometer were performed. The average results for all measuring points were $3.6 \mathrm{~kg} / \mathrm{cm}^{2}\left(51.3 \mathrm{lb} / \mathrm{in}^{2}\right)$ or $0.35 \mathrm{MPa}(\mathrm{SD}= \pm 0.3)$. The collected results show that soil compaction in the layer 0 to 30 $\mathrm{cm}$ (12 in) is much lower than the level of $0.7 \mathrm{MPa}$ indicated by other researchers as decreasing by $50 \%$ penetration of soil by tree roots (Taylor and Ratliff 1969; Greacen and Sands 1980; Craul 1999; Coder 2000).

\section{Data Analysis}

At this stage of research, each of three streetside tree species was represented by a collection of populations-age classes (Table 1). Every age-homogenous population was randomly divided with statistical software into two parts: a test and a control group. Afterward, test groups of each species served for developing a nonlinear model of multifactorial regression. The other half of the trees (control groups) were to serve as practical model validation.

Regression model presented here is mathematically reflected as a formula with parameters determined with appropriate modules of STATISTICA 7.0 (StatSoft Inc., Tulsa, OK). For the nonlinear regression model, we used the exponential regression module. In this article, we used two ways for presenting the regression model:

- mathematical equation (Equation 1);

- graphic interpretation - nomograms (Figure 1, an example and Figures 2, 3, and 4).

Formula 1. The mathematical equation of non-linear regression model.

$$
\text { Age }=-a+e^{\left(b+c \cdot \frac{\overline{D B H}}{100}+d \cdot \bar{H}\right)}
$$

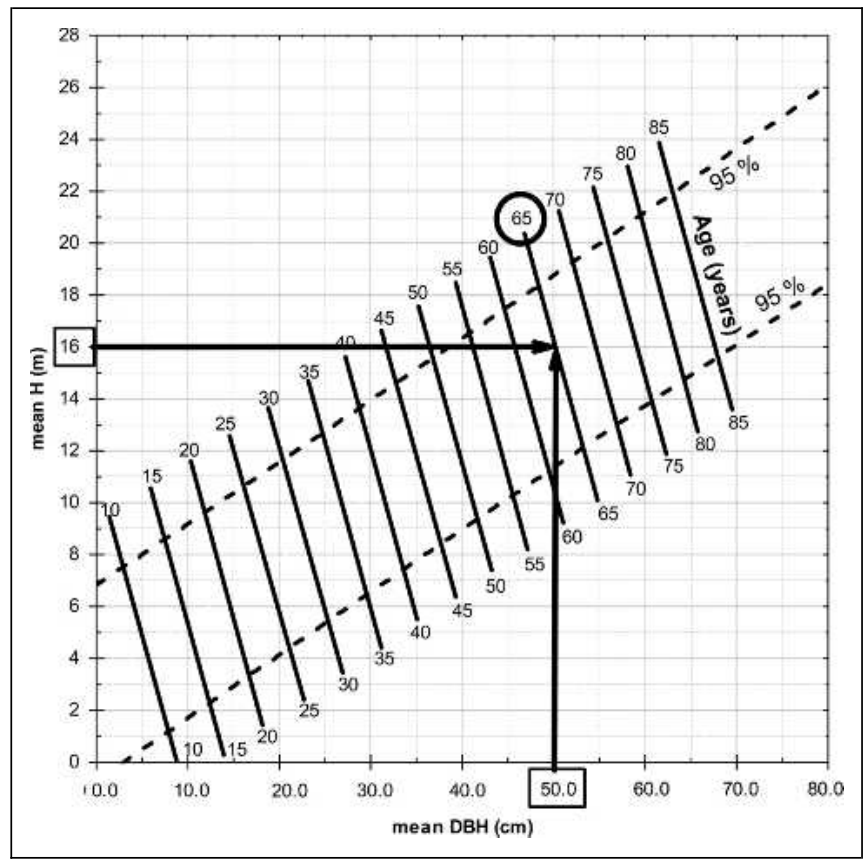

Figure 1. An example of age readout from the common lime (Tilia cordata Mill.) nomogram.

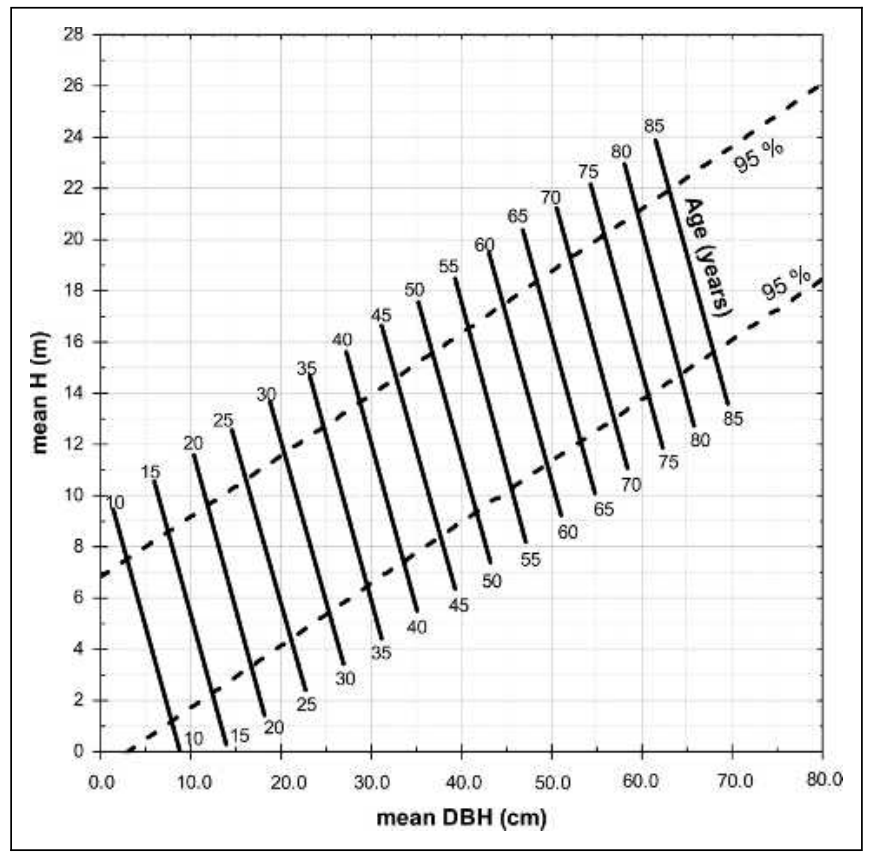

Figure 2. Common lime (Tilia cordata Mill.) nomogram. The nomogram contains age lines in 5-year intervals in a range of 10 to 85 years. The area limited with hashed lines contains $95 \%$ calculated age values of all unrelated trees of known age taken from a control group.

The discussed regression model for each tree species was estimated with the "least squares" method. Mathematical equation factors $(a, b, c, d)$ obtained for each species are included in Table 2. Constant $e$ equals 2.7183. Each time, the regression

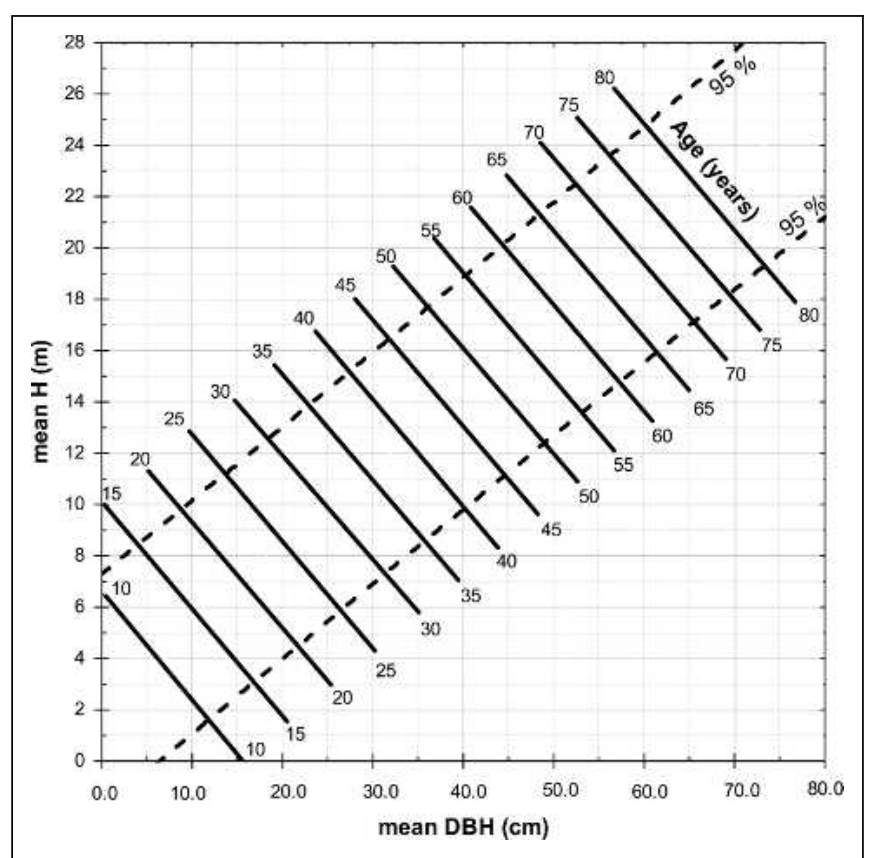

Figure 3. Common ash (Fraxinus excelsior L.) nomogram. The nomogram contains age lines in 5-year intervals in a range of 10 to 80 years. The area limited with hashed lines contains $95 \%$ calculated age values of all unrelated trees of known age taken from a control group. 


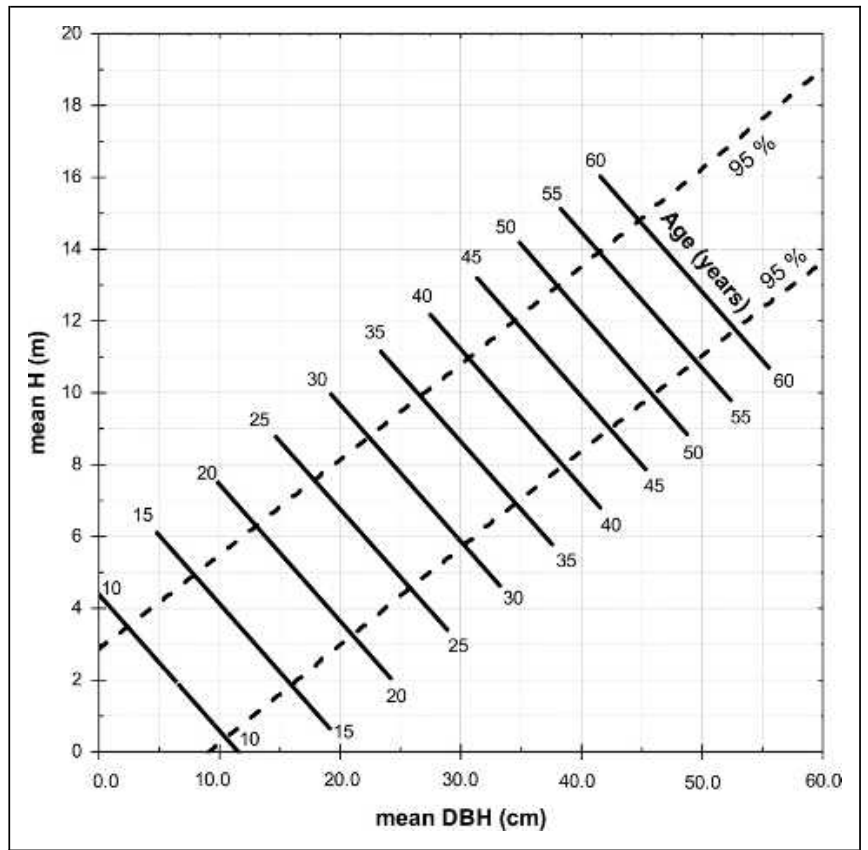

Figure 4. Horsechestnut (Aesculus hippocastanum L.) nomogram. The nomogram contains age lines in 5-year intervals in a range of 10 to 60 years. The area limited with hashed lines contains $95 \%$ calculated age values of all unrelated trees of known age taken from a control group.

coefficient (r) was presented together with its significance level $(P)$ and determination coefficient $\left(\mathrm{r}^{2}\right)$. Regression and determination coefficients elaborated for each species indicated that over $90 \%$ of age value variation is explained by dbh and tree height values variation (Table 2).

\section{RESULTS}

\section{Determining of Multifactorial Regression Model}

The obtained nomograms (Figures 2, 3, and 4) are an attempt to transfer a tridimensional interrelation (three parameters: age, $\mathrm{dbh}$, height) onto a flat surface, which by nature requires using a two-coordinate system. For this reason, it is impossible to read tree age as a continuous parameter and an approximate readout is enforced, e.g., in 5-year intervals, as used in this article. The lines separating age brackets on the nomograms were obtained

Table 2. Equation factors of regression model for each tree species in which Age - the calculated age of street tree population (years); $D B H$ - mean $\mathrm{dbh}(\mathrm{cm})$ taken from street trees population; $\boldsymbol{H}$ - mean total height $(\mathrm{m})$ of street tree population.

\begin{tabular}{lccc}
\hline Factor & Common lime & Common ash & Horsechestnut \\
\hline$a$ & 264.073 & 210.115 & 54.2714 \\
$b$ & 5.5834 & 5.3523 & 4.0709 \\
$c$ & 0.3397 & 0.2655 & 0.7988 \\
$d$ & 0.0026 & 0.0064 & 0.0209 \\
$\mathrm{r}$ & 0.9491 & 0.9857 & 0.9635 \\
$P$ & $<0.001$ & $<0.001$ & $<0.001$ \\
$\mathrm{r}^{2}$ & 0.9009 & 0.9716 & 0.9284 \\
\hline
\end{tabular}

$\mathrm{dbh}=$ diameter at breast height. by substituting a particular tree age (10, 15, 20 years, and so on) into the regression model under research and then by introducing the dbh value typical for the particular age. With known values of age and dbh parameters, the third value of total height was determined by an iteration approach. Iteration means matching the third parameter to the values of the other two by multiple subsequent approximations (Motulsky and Christopoulos 2003). This article used GraphPad application (GraphPad Software, Inc., San Diego, CA) for the purpose. In this way, we obtained a number of pairs of dendrometric parameters for a known age, that is, the dbh and total height which, after being substituted into the model concerned and calculated, determine the particular age.

Consecutive sets of iterations allowed obtaining a number of points for the adopted age value, making possible to draw a line reflecting the specific age value (e.g., 10, 15, 20 years, and so on). The calculations were performed for each age line separately. For instance, a nomogram developed for common lime (Figure 1) shows 16 age lines marking 5-year brackets between the ages of 10 and 85 years. Afterward, age division lines were marked on the coordinate system in which the $\mathrm{X}$-axis reflected $\mathrm{dbh}$ values and the $\mathrm{Y}$-axis reflected total tree height. The area between thick broken lines contains $95 \%$ of tree age values from the control group. The lines were drawn based on prediction intervals for the $\mathrm{dbh} /$ height relation.

\section{Application of Nomograms}

Subsequently is a sample method of a potential field application of a chart with a nomogram. Reading the age with the use of the nomogram should be done especially for these trees complying with the conditions set up in this work (e.g., six streetside common limes). Measurement of dbh and height $(\mathrm{H})$ for each tree is taken. Then mean dbh and mean height for all measured trees in this population is calculated with the result that, for six investigated common lime trees, mean dbh values is $50 \mathrm{~cm}$ (20 in) and the mean height values are $16 \mathrm{~m}(52.8 \mathrm{ft})$. Next we find the values of the mean dbh and the mean $\mathrm{H}$ of trees on the corresponding axis at the common lime nomogram and draw perpendicular lines. The crossing point for both dendrometric parameters (marked with arrows) in this example is pointed at the " 65 years" line (Figure 1). Therefore, the mean age of six streetside common limes is 65 years (range of error is described in the verification part). If the crossing point falls between the age lines, the value should be interpolated.

\section{Verification of the Multifactorial Regression Model}

The credibility of elaborated multifactorial regression model was tested. The verification did not consist of determining whether the regression model is "true" but in seeing whether it generated a fair, verifiable hypothesis on the determination of tree age based on dendrometric parameters.

Initially, we compared the age of trees as determined with the model and the actual age of trees using the control group chosen randomly from the researched tree populations of each species. The control group was not involved in developing the regression model. The dendrometric data of trees from the population were used to arrive at the age of the particular tree using the mathematic version of a particular regression model developed for the species concerned. Hence, each individual tree used to verify the 
regression model under examination was described by two values of the age parameter:

- actual value (known from the source documents and field research); and

- value calculated with the model under verification (Table 3).

The subsequent stage of verification determined the accuracy of the developed regression model. In presented research, accuracy determines the degree of concordance of calculated tree age with actual tree age value. It was described as bias in percentage value calculated with the application of Equation 2.

\section{Formula 2. The accuracy of the method interpreted as} bias (\%).

$$
B I A S=\left(\frac{A g e_{\text {calculated }}-A g e_{\text {actual }}}{A g e_{\text {actual }}} \cdot 100\right) \%
$$

For all populations of sample trees, the calculated age is very close to the actual age; however, accuracy for horsechestnut is less than for other two species. Table 3 presents mean results of age readouts. The verification of independent control groups demonstrated that the model shows accuracy in determining the average age of streetside trees. For each species, the concordance between the average age estimate and actual age described by mean bias did not exceed $15 \%$. At this stage of research, it seems that achieved accuracy (mean bias values) indicate good application potential.

\section{DISCUSSION}

According to the literature (e.g., Brack and Wood 1998; Banks et al. 1999; Peper et al. 2001a, 2001b; Larsen and Kristoffersen 2002; Grabosky and Gilman 2004; Linsen et al. 2005), dbh, basal area, and tree height parameters can be used to predict growth or size of tree dimensions, including height, crown height and radius, leaf area, and so on. Researchers (e.g., Pigott 1989; Peper et al. 2001a, 2001b; Gutsell and Johnson 2002; Larsen and Kristoffersen 2002) focus primarily on examining the growth of dendrometric parameters over time, but they hardly ever examine the issue in reverse order, that is, as time flow (tree aging), as described by changing dendrometric parameters. Undoubtedly, planting dates are one of the key sources of information on tree age. However, the field methods of determining tree age in situ seems to be particularly important in the case of incomplete, fragmented, or lack of inventory data on the actual calendar year of planting trees.

This article presents a model of multifactorial regression, which is rarely found in other research work on the growth of urban trees (e.g., Neely 1988; Banks et al. 1999; Peper et al. 2001b; Larsen and Kristoffersen 2002, Linsen et al. 2005). The presented model allows to effectively determine the age of tree populations based on two dendrometric parameters: mean dbh and $\mathrm{H}$. The use of two parameters simultaneously on nomograms makes for a more reliable outcome of tree age assessment. If the compliance of investigated trees to those ones used by authors is good, the crossing point of mean dbh values and mean $\mathrm{H}$ values should be located between hashed lines $(95 \%$ calculated age values of all unrelated trees of known age taken from a test group) as shown in Figure 1. If this is not the case (age readout outside an area bordered with hashed lines), it means that investigated trees are different (e.g., different density of tree stand, pruning effect, or incomparable site conditions) and their age readout could be biased with significant error.

Potential expansion of research shall take into account different planting locations and site conditions, including downtown areas (very unfavorable for trees) and park areas (optimal conditions for tree growth). In this way, the age assessment of each investigated tree species shall be described by at least three sets of coefficients for the presented regression model. The next step should make it possible to elaborate computer software allowing us to determine tree age based on dendrometric parameters.

It is possible in the future to increase the number of tree species included in the regression model as presented. In the first place, species planted most commonly along streets in Warsaw shall be mentioned [e.g., Norway maple (Acer platanoides L.), Sycamore (Acer pseudoplatanus L.), Silver lime (Tilia tomentosa Moench.), Crimean lime (Tilia $\times$ euchlora Koch.), Red oak (Quercus rubra L.), Rowan (Sorbus aucuparia L.), False acacia (Robinia pseudoacacia L.)]. Besides dbh and height parameters, further research shall take into account the possibility of the

Table 3. Comparison of street trees common lime, common ash, and horsechestnut age classes known and calculated age with multifactorial nonlinear regression model.

\begin{tabular}{|c|c|c|c|c|c|c|c|c|}
\hline \multicolumn{3}{|c|}{ Common lime } & \multicolumn{3}{|c|}{ Common ash } & \multicolumn{3}{|c|}{ Horsechestnut } \\
\hline $\begin{array}{l}\text { Age class } \\
\text { number }\end{array}$ & $\begin{array}{l}\text { Actual age } \mathrm{z}^{\mathrm{z}} \\
\text { (years) }\end{array}$ & $\begin{array}{l}\text { Calcult. age }{ }^{y} \\
\text { (years) }\end{array}$ & $\begin{array}{l}\text { Age class } \\
\text { number }\end{array}$ & $\begin{array}{l}\text { Actual age } \\
\text { (years) }\end{array}$ & $\begin{array}{l}\text { Calcult. age } \\
\text { (years) }\end{array}$ & $\begin{array}{l}\text { Age class } \\
\text { number }\end{array}$ & $\begin{array}{l}\text { Actual age } \\
\text { (years) }\end{array}$ & $\begin{array}{l}\text { Calcult. age } \\
\text { (years) }\end{array}$ \\
\hline 1 & 7 & 7.2 & 1 & 10 & 8.0 & 1 & 16 & 17.8 \\
\hline 2 & 18 & 21.9 & 2 & 16 & 18.0 & 2 & 22 & 27.6 \\
\hline 3 & 25 & 27.9 & 3 & 20 & 21.0 & 3 & 25 & 26.9 \\
\hline 4 & 34 & 35.2 & 4 & 26 & 29.1 & 4 & 30 & 36.0 \\
\hline 5 & 34 & 35.2 & 5 & 43 & 43.5 & 5 & 38 & 33.5 \\
\hline 6 & 36 & 42.2 & 6 & 45 & 45.3 & 6 & 58 & 59.4 \\
\hline 7 & 53 & 49.8 & 7 & 80 & 81.2 & 7 & 60 & 67.3 \\
\hline 8 & 58 & 59.4 & & & & & & \\
\hline 9 & 75 & 66.7 & & & & & & \\
\hline 10 & 85 & 79.5 & & & & & & \\
\hline \multicolumn{2}{|c|}{ Mean bias $(\%)$} & 3.9 & Mean bias & & 1.8 & \multicolumn{2}{|c|}{ Mean bias (\%) } & 9.5 \\
\hline
\end{tabular}

${ }^{\mathrm{z}}$ The actual age of trees taken from historical records or/and tree rings number (Pressler borer).

${ }^{\mathrm{y}}$ Age calculated with developed multifactorial regression model applied on trees' dbh and height of each species taken from the control group.

$\mathrm{dbh}=$ diameter at breast height. 
prediction of tree crown radius with age, because this is a useful parameter in urban designs.

\section{CONCLUSIONS}

The described method of determining the age of streetside tree populations based on the multifactorial regression model can find its use in situations when we have a positive knowledge about the origin of trees but the age remains unknown, whereas the invasive methods could be used in other cases, especially for single trees.

The developed model is accurate and precise enough to determine the mean age of tree populations of low density such as the streetside and roadside locations (6b hardiness subzone). In such cases, the age readout error does not exceed $\pm 15 \%$.

Graphic presentation of the nonlinear multifactorial regression model as nomograms has no equivalent in the cited analysis of professional literature. Nomograms find practical application in field conditions (as it is presented in the provided example; Figure 1), allowing for easy readouts of the age of homogenous populations of roadside trees.

Further investigation should provide a comparison of tree species mentioned in this article to see if they share any growth trends; if so, it would suggest a potential for transfer regression model to another tree species, which shows similar growth.

Although the usefulness of nomograms presented in this article is limited to the tree species growing in sites and climate similar to those reported here, the method has a general application to tree population in any city.

This research serves as a basis for developing a more universal method. The method is, at present, at its developmental stage and can be expanded with additional tree species. Currently obtained results should serve as a starting point for more extensive research of the streetside tree population to determine the relation between their age and dendrometric parameters and environmental factors.

\section{LITERATURE CITED}

Assman, E. 1968. The Principles of Forest Yield Studies. PWRiL, Warsaw, Poland.

Banks, J.C., C.L. Brack, and R.N. James. 1999. Modeling changes in dimensions, health status and arboricultural implications for urban trees. Kluwier Urban Ecosystems 3:35-43.

Bolibok, L., and B. Brzeziecki. 2000. The analyze of selected allometrical relationships of main tree species in Bialowieza National Park. Sylwan Year CXLIV 6:73-81.

Brack, C.L., and G.B. Wood. 1998. Forest Mensuration. Measuring Trees, Stands and Forests for Effective Forest Management. Tree Growth and Increment. http://sres.anu.edu.au (accessed 9/24/2005).

Brzeziecki, B. 1999. Ecological Model of Forest Stand. Principles of Construction and Parametrization. Fundacja Rozwój SGGW, Warsaw, Poland.

Cermak, J., J. Hruska, M. Martinkova, and A. Prax. 2000. Urban tree root systems and their survival near houses analyzed Rusing ground penetrating radar and sap flow techniques. Plant and Soil 219: 103-116.

Coder, K.D. 2000. Soil Compaction \& Trees: Causes, Symptoms \& Effects. University of Georgia USA, July. www.ag.iastate.edu/ departments/forestry/ext/roadside_tree_management/for00-003.pdf (accessed 1/15/2006).

Craul, P.J. 1999. Urban Soils. Application and Practices. Wiley, New York.
Frank, S., G. Waters, R. Beer, and P. May. 2006. An analysis of the street tree population of greater Melbourne at the beginning of the 21st century. Arboriculture and Urban Forestry 32:109-115.

Gardner, S. 2006. 'Selling' Urban Forestry in Your Town. USDA Forest Service. Center for Urban Forest Research. www.fs.fed.us/psw/ programs/cufr/products/powerpoint/cufr_653_35_Selling\%20U.F._ St.Louis.swf (accessed 9/4/2006).

Geiger, J.R., and E.G. McPherson. 2004. Desert Southwest Community Tree Guide. USDA Forest Service. Center for Urban Forest Research. Pacific Southwest Research Station.

Grabosky, J., and E. Gilman. 2004. Measurement and prediction of tree growth reduction from tree planting space in established parking lots. Journal of Arboriculture 30:154-165.

Grabowsky, J., N. Bassuk, and P. Trowbridge. 2002. Structural Soils: A New Medium to Allow Urban Trees to Grow in Pavement. LATIS Cornell University, Washington, DC.

Greacen, E.L., and R. Sands. 1980. Compaction of forest soils-a review. Australian Journal of Soil Research 8:163-169.

Greenberg, C.H., and R.W. Simons. 1999. Age composition and stand structure of old-growth oak sites in the Florida high pine landscape: Implications for ecosystem management and restoration. Natural Areas Journal 19:30-40.

Gutsell, S.L., and E.A. Johnson. 2002. Accurately ageing trees and examining their height-growth rates: Implications for interpreting forest dynamics. British Ecological Society. Journal of Ecology 90: $153-166$

Heinze, W., and D. Schreiber. 1984. A new mapping of hardiness zones for trees and shrubs in Europe. Mitteilungen der Deutschen Dendrologischen Gesellschaft 75:11-56.

Kaennel, M., and F.H. Schweingruber. 2004. Glossary of Dendrochronology. www01.wsl.ch/glossary (accessed 7/9/2006).

Kosmala, M. 2001. Tree root systems. Mat. Ogólnopolskiej Konferencji Naukowo-Technicznej, Warszawa-Powsin 4.10.2001:57-72.

Larsen, F.K., and P. Kristoffersen. 2002. Tilia's physical dimensions over time. Journal of Arboriculture 28:209-214.

Linsen, L., B.J. Karis, G. McPherson, and B. Hamann. 2005. Tree growth visualization. The Journal of WSCG 13:81-88.

Loevenstein, E.F., P.S. Johnson, and H.E. Garrett. 2000. Age and diameter structure of a managed uneven-aged oak forest. Canadian Journal of Forestry Resources 30:1060-1070.

Lomnicki, A. 2002. Introduction to Statistics for Naturalists. PWN, Warsaw, Poland.

McPherson, E.G. 2006. I-Tree: Demonstrating that Trees Pay Us Back. USDA Forest Service. Center for Urban Forest Research. www. fs.fed.us/psw/programs/cufr/products/powerpoint/cufr_650_48_ Webcast_04-25-06a.swf (accessed 10/10/2006).

- 2007. Benefit-based tree valuation. Arboriculture and Urban Forestry 33:1-11.

McPherson, E.G., S.E. Maco, J.R. Simpson, P.J. Peper, Q. Xiao, and A.E. Van der Zanden. 2002. North Western Washington and Oregon Community Tree Guide: Benefits. Costs and Strategic Planting. International Society of Arboriculture, Pacific Northwest Chapter, Silverton, OR.

Motulsky, H.J., and A. Christopoulos. 2003. Fitting Models to Biological Data Using Linear and Nonlinear Regression. A Practical Guide to Curve Fitting. GraphPad Software Inc., San Diego CA. www. graphpad.com (accessed 4/11/2006).

Neely, D. (Ed.). 1988. Valuation of Landscape Trees, Shrubs and Other Plants. 7th Ed. International Society of Arboriculture, Urbana, IL.

Neter, J., and W. Wassermann. 1974. Applied Linear Statistical Models. Richard D. Irwin, Inc., Homewood, IL.

Olig, A.G., and R.W. Miller. 1997. A Guide to Street Tree Inventory Software. www.na.fs.fed.us/spfo/pubs/uf/streettree/toc.htm (accessed 7/25/2006).

Peper, P.J., E.G. McPherson, and S.M. Mori. 2001a. Predictive equations for dimensions and leaf area of coastal South California street trees. Journal of Arboriculture 27:169-180. 
2001b. Equations for predicting diameter. height. crown radius and leaf area of San Joaquin Valley street trees. Journal of Arboriculture 27:306-317.

Pigott, C.D. 1989. Estimation of the age of lime-trees (Tilia ssp.) in parklands from stem diameter and ring counts. Arboricultural Journal 13:289-302.

Shigo, A. 1996. Troubles In the Rhizosphere. Tree Care Industry 10. Vol. VII. www.chesco.com (accessed 11/13/2005).

Skinner, H.T. 1960. Plant Hardiness Zone Map. U.S.D.A. Miscellaneous Publication No. 814.

Sokal, R.R., and F.J. Rohlf. 1981. Biometry. The Principles and Practice of Statistics in Biological Research. 2nd Ed. W.H. Freeman and Company, New York.

Sterck, F.J., F. Schieving, A. Lemmens, and T.L. Pons. 2005. Performance of trees in forest canopies: Explorations with a bottom-up functional-structural plant growth model. The New Phytologist 166: 827-843. www.newphytologist.org (accessed 7/14/2006).

Szczepanowska, H.B. 2001. Trees in the City. Hortpress Sp. z o.o., Warsaw, Poland.

Taylor, H.M., and L.F. Ratliff. 1969. Root growth pressures of cotton, peas and peanuts. Agronomy Journal 61:398-402.

\section{Jan Lukaszkiewicz \\ Assistant Professor \\ Department of Landscape Architecture \\ Warsaw University of Life Sciences-SGGW \\ ul. Nowoursynowska 159/37 \\ 02-776 Warsaw, Poland \\ jan_lukaszkiewicz@sggw.waw.pl}

Marek Kosmala (corresponding author)

Associate Professor

Department of Landscape Architecture

Warsaw University of Life Sciences-SGGW

ul. Nowoursynowska 159/37

02-776 Warsaw, Poland

marek_kosmala@sggw.pl

Résumé. Cet article évalue la possibilité de déterminer l'âge d'un arbre en se basant simultanément sur le DHP (mesuré à 1,3 m du sol) et la hauteur totale, et ce dans le cas du citronnier commun, du frêne commun et du marronnier d'Inde. La première étape a été d'identifier et de mesurer des groupes d'arbres croissant dans des conditions similaires (arbres de rues à Varsovie en Pologne) et dont l'âge de plantation était connu (la plupart du temps à partir d'archives). Par la suite des modèles multifactorielles de régression ont été développés afin de décrire la croissance des deux paramètres des arbres (DHP et hauteur) dans le temps. Dans la majorité des cas, l'âge des lots d'arbres par rapport au diamètre et à la hauteur a donné une valeur de coefficient de régression $r$ et permis de déterminer une valeur de coefficient $r^{2}$ supérieure à 0,9 .
Des nomogrammes ont été appliqués pour l'interprétation graphique des modèles multifactoriels élaborés. Ce type de graphique permet d'expliquer l'âge des arbres en se basant à la fois sur le DHP et la hauteur des arbres. Une autre étape a été celle de la vérification. Les modèles qui ont résulté ont été appliqués à des groupes non reliés d'arbres dont l'âge était inconnu. Des valeurs moyennes ont été établies pour chaque modèle. La différence entre l'âge réel et l'âge calculé à partir du modèle était de $\pm 15 \%$. Les modèles présentés, même s'ils ne sont conçus pour s'appliquer à des arbres individuels, peuvent s'avérer utiles pour déterminer l'âge des groupes d'arbres le long des rues et des routes.

Zusammenfassung. Diese Studie bewertet die Möglichkeit der Altersbestimmung bei Bäumen, basierend auf Brusthöhendurchmesser und Baumhöhe bei Linden, Eschen und Rosskastanien. Der erste Schritt war der zur Identifikation und die Messung von Baumgruppen, die unter ähnlichen Konditionen (Straßenbäume in Warschau) wuchsen und deren Alter anhand der Unterlagen bekannt war. Dann wurden faktorenreiche Regressionsmodelle entwickelt, um die beiden Parameter über die Zeit zu messen. In der Mehrzahl der Fälle ergab ein Plotten des Baumalters gegen Durchmesser und Höhe einen Regressionskoeffizienten $r$ wert und einen Bestimmungskoeffizienten $r^{2}$ über 0,9. Für die graphische Interpretation der faktorenreichen Modelle wurden Nomogramme angewendet. Diese Art von Graph erlaubt eine Altersbestimmung, basierend auf Durchmesser und Höhe. Ein anderer Schritt war eine Verifizierung. Die resultierenden Modelle wurden auf neue Baumgruppen bekannten Alters anzuwenden. Mittlere BIAS-Werte wurden für jedes Modell festgeschrieben. Der Unterschied zwischen dem aktuellen Alter und dem mittleren Alter nach den Modellen betrug weniger als $15 \%$. Die präsentierten Modelle, auch wenn sie nicht für individuelle Bäume zutreffen mögen, können bei der Altersbestimmung von Straßenbäumen nützlich sein.

Resumen. Este reporte evalúa la posibilidad de determinar la edad del árbol con base en el diámetro al nivel del pecho (DBH, por sus siglas en inglés) (1.3 m (4.3 pies)) y la altura total del árbol, usando especies comunes de lima, fresno y castaño. El primer paso fue la identificación y medición de grupos de árboles creciendo en condiciones similares (lado de la calle en el área de Varsovia, Polonia), de los que la edad de plantación fue conocida (principalmente por archivos). Enseguida se emplearon modelos de análisis multifactorial describiendo el crecimiento de ambos parámetros de los árboles (DBH y altura) sobre el tiempo. En la mayoría de los casos, el ploteo de la edad del árbol contra el diámetro y la altura dieron un valor $\mathbf{r}$ del coeficiente de regresión y coeficiente de determinación $\mathrm{r}^{2}$ arriba de 0.9 . Por interpretación gráfica fueron aplicados los nomogramas de los modelos multifactoriales elaborados. Este tipo de gráfica permite explicar la edad del árbol con base en el DBH y la altura de los árboles. Otro paso fue una verificación. Los modelos resultantes fueron aplicados en grupos no relacionados de árboles de edad conocida. Los valores medios BIAS fueron establecidos para cada modelo. La diferencia entre la edad real y la edad media calculada con el modelo fue menor a $\pm 15 \%$. Los modelos presentados, aunque no pueden ser aplicados a árboles individuales, pueden ser útiles para determinar la edad de grupos de árboles que crecen en calles y avenidas. 